\title{
Wildlife predation on livestock and poultry: implications for predator conservation in the rainforest of south-east Mexico
}

\author{
Saúl Amador-Alcalá, Eduardo J. Naranjo and Guillermo Jiménez-Ferrer
}

\begin{abstract}
We assessed wildlife predation on livestock and poultry and the implications for predator conservation in the most important rainforest areas of south-east Mexico. We estimated the economic impact of predation and identified variables correlated to predation frequency in four communities adjacent to Calakmul and Montes Azules Biosphere Reserves. We did participant observation and interviews with 161 residents during January-September 2010. We recorded 2,861 deaths of livestock and poultry from predation by wild carnivores over the previous 3 years. Opossums $(n=677$ predation events), raptors $(n=676)$ and ocelots $(n=539)$ were responsible for the highest numbers of killings. Poultry constituted the main target of wild predators $(n=2,548$ deaths). Sheep $(n=201$ events) and cattle (167) were the most affected by large predators such as jaguar Panthera onca and puma Puma concolor. Economic losses from predation were estimated to be USD 55,600 over the 3 years in the four communities. Predation frequency was positively correlated with livestock numbers $\left(r^{2}=0.87, \mathrm{P}<0.05\right)$ but negatively associated with wild prey abundance $\left(r^{2}=0.96, \mathrm{P}<0.05\right)$. Better husbandry practices focused on the safety and location of livestock enclosures and on reducing overabundance of dogs and regulating hunting on wild prey in rural areas may help mitigating conflict between wild predators and residents in the rainforests of south-east Mexico.
\end{abstract}

Keywords Calakmul, Lacandon Forest, Montes Azules, Mexico, predation, Puma concolor, Panthera onca, wildlife conflict

\section{Introduction}

M any wild predators are currently threatened because of habitat loss, overhunting and, particularly, conflict with people and their domesticated fauna. In most situations predators are killed as soon as possible regardless of their conservation status and their role in natural ecosystems (Linnell et al., 1999; Ogada et al., 2003).

Saúl Amador-Alcalá, Eduardo J. Naranjo (Corresponding author) and Guillermo Jiménez-Ferrer El Colegio de la Frontera Sur, Carretera Panamericana y Periferico Sur, San Cristóbal de Las Casas, Chiapas, Mexico E-mail enaranjo@ecosur.mx

Received 9 March 2011. Revision requested 16 May 2011.

Accepted 4 July 2011.
Domesticated animals such as cattle, horses, goats, sheep, pigs, poultry and dogs are important for a significant part of the global human population as primary sources of meat, milk, fat, hides, workforce and companions, among many other products and benefits (De Haan et al., 2001). These animals constitute the main economic and dietary assets of a high proportion of rural residents (Romañach et al., 2007). In southern Mexico most people in rural communities keep livestock and poultry as an additional source of income that constitute savings to be used in emergencies and for festivities and other special occasions. Villagers in Mexico and other developing countries will not hesitate to take measures against predation on their livestock, and retribution for predation is a major cause of carnivore declines (Baker et al., 2008). Developing strategies and techniques to mitigate conflicts between wild predators and rural residents is required to improve the conservation of carnivores (Hoogesteijn \& Hoogesteijn, 2008; Inskip \& Zimmermann, 2009).There have been few surveys of predation of livestock by large carnivores (mainly puma Puma concolor and jaguar Panthera onca) in the semi-arid lands and seasonal forests of northern Mexico, where cattle raising is probably the most important economic activity. Livestock losses to predation are, however, known to be low compared to the impact of disease, drought, theft and other threats (Bueno, 2004; Rosas et al., 2008). In south-east Mexico's tropical rainforest, where people's economy increasingly relies on raising livestock and poultry, there have been no previous analyses of predation by wildlife on livestock.

The study reported here was carried out in rural communities within the two most important tracts of tropical rainforest remaining in Mexico: Calakmul and the Lacandon Forest. Mammalian predators such as puma, jaguar, ocelot Leopardus pardalis, margay Leopardus wiedii, jaguarundi Puma yaguarondi, grey fox Urocyon cinereoargenteus, tayra Eira barbara, grison Galictis vittata, skunks (Mephitidae), cacomistle Bassariscus sumichrasti, raccoon Procyon lotor and opossums (Didelphidae) occur in both areas. Raptors such as hawks, eagles and kites (Accipitridae), falcons (Falconidae) and large snakes (e.g. Boa constrictor) and crocodiles (Crocodylus spp.) also occur in south-east Mexico and prey on livestock and poultry (Leopold, 1959; Naranjo et al., 2004). The two study areas contribute to the maintenance of wild predators in Mexico and probably contain the last viable populations of jaguars in the country (Ceballos \& Oliva, 2005). 

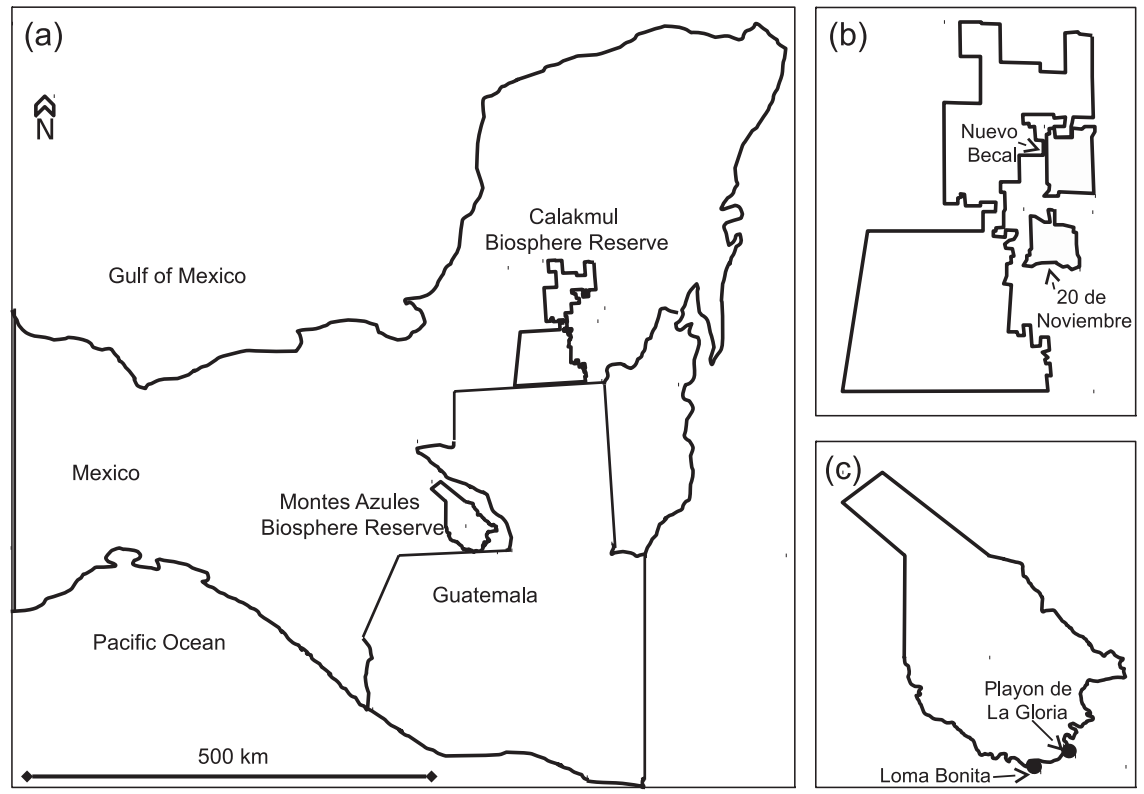

FIg. 1 (a) Location of the Montes Azules Biosphere Reserve in the Lacandon Forest of the State of Chiapas, and the Calakmul Biosphere Reserve in the State of Campeche, Mexico, and the location of communities adjacent to (b) Calakmul Biosphere Reserve, and (c) Montes Azules Biosphere Reserve.
Conflicts between wild predators and people have already caused extinctions in Mexico. The Mexican wolf Canis lupus baileyi and the grizzly bear Ursus arctos horribilis disappeared 4 and 5 decades ago, respectively (Ceballos \& Simonetti, 2002). Our study aimed to assess wildlife predation on livestock and implications for carnivore conservation in communities around the Calakmul and Montes Azules Biosphere Reserves in south-east Mexico.

\section{Study area}

The 3,312 $\mathrm{km}^{2}$ Montes Azules Biosphere Reserve comprises one of the best preserved tracts of rainforest in the Lacandon Forest of the State of Chiapas, Mexico (Fig. 1). Altitudes are 200-1,500 $\mathrm{m}$, mean annual rainfall is c. 3,000 $\mathrm{mm}$ and mean temperatures are $24-26^{\circ} \mathrm{C}$ (INE, 2000a). The rainforest in this area is host to a rich flora and fauna (INE, 2000a). The two communities (ejidos, a communal form of land tenure in rural Mexico) visited in the Lacandon Forest were Playon de La Gloria (population 250), and Loma Bonita (population 400), both adjacent to Montes Azules Biosphere Reserve on the eastern margin of the Lacantun river. Residents are farmers and most families own some livestock, poultry and dogs. Additional economic activities include subsistence fishing and hunting, and selective timber extraction (Naranjo, 2002).

The $7,232 \mathrm{~km}^{2}$ Calakmul Biosphere Reserve in the State of Campeche forms a core part of the most extensive rainforest remaining in Mexico (Fig. 1). Mean annual temperature and rainfall are $25^{\circ} \mathrm{C}$ and $750 \mathrm{~mm}$ (INE, 200ob). The Calakmul region comprises a mosaic of tropical forest types, with a large number of hardwood trees and wild vertebrates (INE, 200ob). The ejidos selected in Calakmul were Nuevo
Becal (population 420), and 20 de Noviembre (population 350). Both ejidos are contiguous to the Reserve and together contain $850 \mathrm{~km}^{2}$ of which over $50 \%$ is still covered by native rainforest. Inhabitants of both communities make their living from extracting forest products (timber, gum, charcoal and seeds), growing corn and peppers, apiculture and raising cattle and sheep (Arguelles et al., 2009).

\section{Methods}

Surveys were carried out during January-September 2010, after obtaining research permits from the authorities of the four communities. SAA stayed alternately in the two study areas, with a total of c. 160 days of fieldwork. We surveyed predation events and all other causes of death (e.g. disease, snake bite and theft) suffered by livestock and poultry in the four communities during the previous 3 years (2008-2010). This period was chosen after a pilot study in which at least five exploratory interviews were done in each community prior to the extended stays (Mazzolli et al., 1997; Bueno, 2004). At least $90 \%$ of all livestock and poultry breeders were interviewed in each community. Most of the interviews were conducted while visiting the sites where animals were kept (pastures, poultry enclosures and pigsties). When attacks by wild carnivores were detected during the fieldwork, the identity of predators was defined by examining signs and remains, such as footprints, scats and hair, and by observing the pattern of the attack (location and nature of injuries, and parts of victims consumed; Hoogesteijn, 2001; Nallar et al., 2008).

During the interviews the identity of predators and their prey were determined for each event, using field guides (Reid, 1997; Aranda, 2000) and the experience of the livestock breeders. Frequencies, sites, dates, economic losses 
and other details of damage caused by predators were also noted. Livestock management practices and knowledge about predator feeding habits were compiled and quantified, using standard questionnaires. Interviewees were also asked to express their views on damage by wild carnivores, and proposals for mitigation.

To increase the reliability of the information gathered we discarded reported predation events for which interviewees did not find clear evidence of the attacks (remains of prey, footprints or hair of predators; Hoogesteijn, 2001; Nallar et al., 2008), or when they were unsure of the identity of predators. To validate further the information obtained in the interviews we conversed with third persons (usually neighbours and close relatives) aware of predation events on the interviewees' livestock. Inconsistent data between interviewees and third persons were excluded from the analyses.

Animal losses recorded in the study were categorized as losses from predation by wild carnivores and losses attributable to factors such as disease, theft and drought. Mann-Whitney's rank sum tests were used to detect differences in losses between the two categories within each community and study site (Zar, 1999). Economic damage caused by predators in each community was estimated by calculating the proportional value of livestock per livestock breeder ( = value of killed animals/value of total livestock per livestock breeder; Bueno, 2004). Frequencies of predation on cattle, sheep and equines were tested for correlation (Zar, 1999) with their numbers in each community, wild prey abundance, community size (ha) and enclosure size. Prey abundance was estimated between February and December 2010 using line transect sampling along $314 \mathrm{~km}$ of trails in the various habitat types of the four communities (Amador, 2011). Statistical analyses were performed using SPSS v. 15.o (SPSS, Chicago, USA).

\section{Results}

A total of 181 residents were interviewed, 84 and 77 from Calakmul and the Lacandon Forest, respectively. The data from 20 interviews were considered unreliable and consequently excluded from analyses. The average age of interviewees was $41 \pm$ SD 10.6 years and most considered themselves farmers and livestock breeders. Residents of the two study areas reported a total of 3,492 animals lost between 2008 and 2010 (Table 1). Losses were because of predation by wild carnivores $(n=2,861)$, rabies transmitted by vampire bats (Desmodontinae; $n=145)$, other diseases $(n=462)$, snake bites $(n=18)$ and theft $(n=6)$. Predation events were more frequent in pastures ( $83 \%$ ), followed by barnyards within the communities (14\%) and forest fragments (3\%).

Poultry was the most frequent prey $(85.7 \%$ of predation events recorded) of wild carnivores, followed by sheep and goats $(6.7 \%)$, cattle $(5.5 \%)$, dogs (1.1\%), equines (0.6\%) and pigs (0.4\%). The most frequent predation events were by opossums and raptors (Table 2). Jaguars and pumas were the most frequent predators of calves, horses, sheep and goats. Other causes of loss were diseases (anthrax, brucellosis and Newcastle disease), snake bites (mainly by Bothrops spp.) and theft (Table 1). We also recorded 139 wild carnivores shot by livestock breeders in Calakmul and 195 in Lacandon Forest (Table 3). The 2,861 predated animals in the four communities represented losses equivalent to USD 55,600 (Table 1). These losses were slightly higher than those attributed to all other causes of death combined (USD 54,576). Poultry losses were the highest (USD 22,760), followed by cattle (USD 21,504), sheep and goats (USD 7,880), equines (USD 2,160), dogs (USD 816) and pigs (USD 480). The mean financial loss per livestock breeder was USD 115.

The larger predators (jaguars and pumas) frequently preyed on sheep in all communities except for 20 de

TABLE 1 Mean number of livestock, poultry and dogs held per year (for 2008-2010), and total number of livestock lost (and financial loss in USD) to predation by wild carnivores and other causes (rabies, disease, theft and snake bite) in four communities, combined, around Montes Azules and Calakmul Biosphere Reserves (Fig. 1) during 2008-2010. Costs were estimated in USD per kg in local markets. Cattle: USD $1.06 \mathrm{~kg}^{-1}$ up to $200 \mathrm{~kg}$, thereafter USD $0.82 \mathrm{~kg}^{-1}$. Sheep and goats: USD 16.44 per animal (young and juveniles) and USD 49.34 per animal (adults). Equines: USD 82-411 per animal depending on age and training. Pigs: USD 16-82 per animal depending on age and weight. Poultry: chickens and ducks USD 8 per animal (adults), turkeys USD 12 per animal. Dogs: USD 16-82 per animal depending on pedigree and degree of training for hunting.

\begin{tabular}{|c|c|c|c|c|c|c|c|}
\hline & $\begin{array}{l}\text { Mean no. } \\
\text { held } \pm \text { SD }\end{array}$ & $\begin{array}{l}\text { Predated } \\
\text { (USD) }\end{array}$ & $\begin{array}{l}\text { Rabies } \\
\text { (USD) }\end{array}$ & $\begin{array}{l}\text { Other diseases } \\
\text { (USD) }\end{array}$ & $\begin{array}{l}\text { Theft } \\
\text { (USD) }\end{array}$ & $\begin{array}{l}\text { Snake bite } \\
\text { (USD) }\end{array}$ & $\begin{array}{l}\text { Total losses } \\
\text { (USD) }\end{array}$ \\
\hline Cattle & $2,106 \pm 207.8$ & $62(21,504)$ & $105(26,376)$ & $84(14,400)$ & $6(1,440)$ & $18(4,320)$ & $275(68,040)$ \\
\hline $\begin{array}{c}\text { Sheep \& } \\
\text { goats }\end{array}$ & $630 \pm 42.7$ & $197(7,880)$ & $4(160)$ & $109(4,360)$ & 0 & 0 & $310(12,400)$ \\
\hline Equines & $121 \pm 21.7$ & $8(2,160)$ & $2(640)$ & $3(480)$ & 0 & 0 & $13(3,280)$ \\
\hline Pigs & $195 \pm 39.3$ & $12(480)$ & 0 & 0 & 0 & 0 & $12(480)$ \\
\hline Poultry & $4,541 \pm 499.3$ & $2,548(22,760)$ & $34(272)$ & $266(2,128)$ & 0 & 0 & $2,848(25,160)$ \\
\hline Dogs & $241 \pm 26.0$ & $34(816)$ & 0 & 0 & 0 & 0 & $34(816)$ \\
\hline Total & 7,834 & $2,861(55,600)$ & $145(27,448)$ & $462(21,368)$ & $6(1,440)$ & $18(4,320)$ & $3,492(110,176)$ \\
\hline
\end{tabular}


TABLE 2 Numbers of livestock predated by wildlife as reported by livestock breeders in four communities, combined, around Montes Azules and Calakmul Biosphere Reserves (Fig. 1) during 2008-2010.

\begin{tabular}{|c|c|c|c|c|c|c|c|}
\hline Predator & Cattle & Sheep \& goats & Equines & Pigs & Poultry & Dogs & Total \\
\hline Opossum Didelphis sp. & 0 & 0 & 0 & 0 & 677 & 0 & 677 \\
\hline Birds of prey & 0 & 0 & 0 & 0 & 676 & 0 & 676 \\
\hline Ocelot Leopardus pardalis & 0 & 0 & 0 & 0 & 539 & 0 & 539 \\
\hline Grey fox Urocyon cinereoargenteus & 0 & 0 & 0 & 0 & 331 & 0 & 331 \\
\hline Jaguar Panthera onca & 54 & 160 & 7 & 11 & 8 & 30 & 270 \\
\hline Jaguarundi Puma yaguarondi & 0 & 0 & 0 & 0 & 147 & 0 & 147 \\
\hline Boa Boa constrictor & 0 & 0 & 0 & 0 & 87 & 0 & 87 \\
\hline River otter Lontra longicaudis & 0 & 0 & 0 & 0 & 32 & 0 & 32 \\
\hline Cougar Puma concolor & 2 & 26 & 0 & 1 & 1 & 0 & 30 \\
\hline Owls Strigiformes & 0 & 0 & 0 & 0 & 24 & 0 & 24 \\
\hline Large feline (unknown) & 1 & 11 & 1 & 0 & 0 & 2 & 15 \\
\hline White-nosed coati Nasua narica & 0 & 0 & 0 & 0 & 10 & 0 & 10 \\
\hline Tayra Eira barbara & 0 & 0 & 0 & 0 & 10 & 0 & 10 \\
\hline Black vulture Coragyps atratus & 5 & 0 & 0 & 0 & 0 & 0 & 5 \\
\hline Rodents & 0 & 0 & 0 & 0 & 4 & 0 & 4 \\
\hline Cacomistle Bassariscus sumichrasti & 0 & 0 & 0 & 0 & 2 & 0 & 2 \\
\hline American crocodile Crocodylus acutus & 0 & 0 & 0 & 0 & 0 & 2 & 2 \\
\hline Total & 62 & 197 & 8 & 12 & 2,548 & 34 & 2,861 \\
\hline
\end{tabular}

TABLE 3 Estimates of wild predators killed during 2008-2010 in retaliation for preying on livestock and poultry in four communities around Montes Azules and Calakmul Biosphere Reserves (Fig. 1).

\begin{tabular}{lccclr}
\hline & $\begin{array}{l}\text { Playon } \\
\text { de La } \\
\text { Species }\end{array}$ & $\begin{array}{l}\text { Loma } \\
\text { Gloria }\end{array}$ & $\begin{array}{l}\text { Nuevo } \\
\text { Bonita }\end{array}$ & $\begin{array}{l}\text { 20 de } \\
\text { Boviembre }\end{array}$ & Total \\
\hline Opossum & 100 & 80 & 60 & 66 & 306 \\
Jaguar & 3 & 0 & 3 & 2 & 8 \\
Ocelot & 3 & 3 & 1 & 0 & 7 \\
Boa & 1 & 3 & 0 & 0 & 4 \\
Tayra & 0 & 0 & 2 & 2 & 4 \\
Grey fox & 1 & 0 & 1 & 0 & 2 \\
Birds of prey & 0 & 0 & 1 & 0 & 1 \\
Cougar & 0 & 0 & 1 & 0 & 1 \\
River otter & 1 & 0 & 0 & 0 & 1 \\
Total & 109 & 86 & 69 & 70 & 334 \\
\hline
\end{tabular}

Noviembre, where these predators killed more pigs and dogs. Medium-sized carnivores (ocelot, jaguarundi and grey fox) preyed on poultry (Table 2). Frequencies of predation by jaguars and pumas were higher at distances $<100 \mathrm{~m}$ from dense vegetation in the communities of Lacandon Forest (Spearman's $r=1, \mathrm{P}<0.05, \mathrm{n}=2$ ), and in the four communities combined $(r=0.96, \mathrm{P}=0.03, \mathrm{n}=4)$ but not in the communities of Calakmul $(r=0.8, \mathrm{P}=0.16, \mathrm{n}=2)$. Seventy-four percent of jaguar attacks were recorded in pastures at distances $<100 \mathrm{~m}$ from the surrounding forest. Other jaguar attacks occurred within forest fragments (11\%) and gardens surrounding houses (15\%).

There was a positive correlation overall between frequency of predation of livestock and poultry and their number (Spearman's $r=0.87, \mathrm{P}<0.05, \mathrm{n}=12$ ) and in each community separately: Playon de La Gloria $r=0.60$, $\mathrm{P}<0.05, \mathrm{n}=30$; Loma Bonita $r=0.77, \mathrm{P}<0.05, \mathrm{n}=39$; Nuevo Becal $r=0.61, \mathrm{P}<0.05, \mathrm{n}=45 ; 20$ de Noviembre $r=0.72, \mathrm{P}<0.05, \mathrm{n}=36$. Overall frequency of predation on livestock and poultry was also negatively correlated with the abundance of wild prey $(r=0.96, \mathrm{P}<0.05, \mathrm{n}=4$; Table 4), and with rainforest cover only in Loma Bonita $(r=0.34, \mathrm{P}=0.02, \mathrm{n}=41)$. Predation on poultry always occurred in agricultural cover, where killings of cattle, sheep, equines and dogs were also more frequent in Playon de La Gloria $(r=0.41, \mathrm{P}=0.02, \mathrm{n}=30)$ and Nuevo Becal $(r=0.39, \mathrm{P}=0.007, \mathrm{n}=47)$.

\section{Discussion}

The capacity for recalling details of past events is highly variable among individuals; thus, the reliability of information given by interviewees is always subject to potential bias. Bueno (2004) and Mazzolli et al. (1997) found that a reasonable period for recollection by livestock breeders of predation is up to 2 years after the loss of an animal. Following this suggestion, at the start of our study in January 2010 we queried residents of the two study areas for predation events that occurred between January 2008 and December 2009. We added this information to the predation events recorded during 2010. Confirming data from interviews with third persons added confidence to our results. Nevertheless, we recognize that predation on poultry could have been underestimated (when the informant did not recall the exact number of birds predated in a single event we recorded it as one bird), and some interviewees 
TABLE 4 Abundance of wild prey in the four communities around Montes Azules and Calakmul Biosphere Reserves (Fig. 1). Indices (number per $\mathrm{km}$ ) are based on sightings and signs detected along $314 \mathrm{~km}$ of transects during February-December 2010.

\begin{tabular}{|c|c|c|c|c|}
\hline Species & $\begin{array}{l}\text { Playon de } \\
\text { la Gloria }\end{array}$ & $\begin{array}{l}\text { Loma } \\
\text { Bonita }\end{array}$ & $\begin{array}{l}\text { Nuevo } \\
\text { Becal }\end{array}$ & $\begin{array}{l}20 \mathrm{de} \\
\text { Noviembre }\end{array}$ \\
\hline Great tinamou Tinamus major & 0.25 & 0.21 & 0.15 & 0.34 \\
\hline Great curassow Crax rubra & 0.13 & 0.01 & 0.56 & 0.26 \\
\hline Plain chachalaca Ortalis vetula & 0.13 & 0.15 & 0.22 & 0.52 \\
\hline Opossum Didelphis sp. & 0.02 & 0.06 & 0.01 & 0.05 \\
\hline Nine-banded armadillo Dasypus novemcinctus & 0.04 & 0.23 & 0.65 & 0.42 \\
\hline Geoffroy's spider monkey Ateles geoffroyi & 1.24 & 0.11 & 0.57 & 0.54 \\
\hline White-nosed coati Nasua narica & 0.03 & 0.03 & 0.18 & 0.68 \\
\hline Baird's tapir Tapirus bairdii & 0.26 & 0.15 & 0.62 & 0.24 \\
\hline Collared peccary Pecari tajacu & 0.13 & 0.25 & 0.29 & 0.47 \\
\hline White-lipped peccary Tayassu pecari & 0.06 & 0.01 & 0.05 & 0.03 \\
\hline Red brocket deer Mazama americana & 0.14 & 0.16 & 2.51 & 1.70 \\
\hline White-tailed deer Odocoileus virginianus & 0.07 & 0.45 & 0.37 & 0.62 \\
\hline Agouti Dasyprocta sp. & 0.01 & 0.06 & 0.02 & 0.67 \\
\hline Paca Cuniculus paca & 0.08 & 0.10 & 0.13 & 0.24 \\
\hline
\end{tabular}

could have overestimated economic losses of predated cattle and sheep (livestock prices vary continuously in the study areas).

Opossums are generally a predator of poultry in rural areas of Mexico (Leopold, 1959) and this was also the case in Calakmul and Lacandon Forest, where opossums were the most common predators. Opossum diet consists of insects, fruit, seeds and occasionally small vertebrates (Reid, 1997; Aranda, 2000). However, these mammals may become opportunistic predators of poultry when available. Chickens, turkeys and ducks are usually free-ranging and abundant in the four communities visited, which may explain the high numbers of attacks on them by opossums. For this reason (possibly enhanced by cultural prejudice), opossums were also the predators most frequently killed by villagers $(\mathrm{n}=306$; Table 3$)$.

Diurnal raptors (Accipiter spp., Buteo spp. and Falco spp.) and owls were the most important predatory birds in the two study areas, taking a total of c. 700 chickens, turkeys and ducks. This is similar to observations on French poultry farms (Stahl et al., 2002), where birds of prey were responsible for $53 \%$ of deaths. Five deaths of calves in our study area were attributed to black vultures Coragyps atratus. Although it is likely that the calves attacked were already ill and weak, there are reports of vultures preying on calves (Lowney, 1999; Avery \& Cummings, 2004). It is unclear whether vultures are capable of killing healthy calves.

Medium-sized carnivores are known to be predators of poultry (Leopold, 1959; Aranda, 2000; Martínez, 2003) but there are no previous reports quantifying this phenomenon in Mexico. The large number of poultry taken by wild cats and grey foxes in our study area reinforces their popular status as threats for poultry breeders. Poultry are relatively abundant in the communities surveyed, whereas small wild prey such as agouties, armadillos, chachalacas, guans and iguanas have been reduced by unregulated hunting and habitat disturbance (Amador, 2011). The grey fox has not been previously reported as a predator of poultry in the Lacandon Forest (Naranjo et al., 2004). The current expansion of this carnivore seems to be related to rainforest fragmentation processes occurring in the area (Naranjo, 2002).

Vampire bats are responsible for a number of animal deaths associated with rabies (Ceballos \& Oliva, 2005). Between January and March 2010 we witnessed an outbreak of rabies in cattle and horses of Playon de La Gloria and Loma Bonita that produced 156 casualties, most of them attributed by livestock breeders to the high numbers of vampire bats present in the area. Yet, it is clear that recent expansion of cattle ranching in the Lacandon Forest (which means more food for vampire bats) exacerbated the situation as most breeders did not vaccinate their animals against rabies before this outbreak.

Predation by reptiles in the two study areas was insignificant: crocodiles hunted two dogs and boas consumed six chickens in communities of the Lacandon Forest. As the numbers of large crocodiles in the Lacantun river and its tributaries are low, it is unlikely that conflicts with reptiles, other than snake bites, will increase.

Economic damage caused by wild predators in Calakmul and Lacandon Forest in a 3-year period (estimated at USD 55,600 , or c. USD 18,533 in 161 households in 1 year) is substantially higher than that reported for Chihuahua and Yucatan in Mexico, where predators inflicted losses of $<$ USD 4,000 a year (Bueno, 2004; Hernández, 2009). Estimated annual costs of predation in other parts of the world, such as the Himalayas (USD 996 in 63 households; Namgail et al., 2007) and Zimbabwe (USD 1,564 in 130 households; Butler, 2000) are lower than our estimates. 
When annual losses are apportioned by breeder the cost in south-east Mexico (USD 115) is lower than that calculated by Mertens \& Promberger (2001) in Romania (USD 395). However, it is difficult to ascertain if these differences are artefacts of the methodologies or because of real variations in predation frequency. It is important to note that we included poultry in estimates of financial losses whereas other studies have excluded them.

Previous research suggests that predation frequency is positively associated with the abundance of livestock (Mertens \& Promberger, 2001; Bueno, 2004; Michalski et al., 2006; Sacks \& Neale, 2007). We found a similar trend in our study areas, especially for cattle, which are frequently maintained in pastures several kilometres from villages, close to forest fragments. Attacks by jaguars and pumas are not infrequent in these conditions, as observed by Polisar et al. (2003) in Venezuela, and for other large predators elsewhere (Woodroffe et al., 2004; Gula, 2008). In our study areas predation was not only associated with livestock abundance but with their spatial distribution as well. This was supported by the fact that most attacks occurred in pastures surrounded by forest fragments or corn fields, which are regularly visited by wild prey such as collared peccaries Pecari tajacu, pacas Cuniculus paca, red brocket deer Mazama americana and white-tailed deer Odocoileus virginianus (Naranjo et al., 2004; Romero et al., 2006; Weber, 2008).

We recognize that c. $5 \%$ of the people we interviewed were unsure of the identity of the large predators killing their livestock. However, most livestock breeders were confident in identifying specific signs (e.g. footprints, hair, and scars left on their victims) of jaguars and pumas, and they were especially interested in explaining the details of these attacks. Azevedo \& Murray (2006) suggested that jaguars generally hunt in forested areas or close to them. We observed a similar pattern in our study sites, which is probably because of the ambush hunting technique used by jaguars (Crawshaw \& Quigley, 2002). One more factor that seemed to have played a role in the frequency of predation by jaguars was distance from livestock enclosures to water sources. This was also observed by Michalski et al. (2006) in Brazil, where predation by jaguars and pumas was higher in the vicinity of water.

Our results indicated that jaguars frequently preyed on sheep in three of the four communities visited. The explanation for this may be the docility and noisy behaviour of sheep compared to other mammals, which make them less risky to hunt. In addition, sheep are usually kept in fragile enclosures surrounded by dense vegetation and close to water sources, which facilitates detection by jaguars (Scognamillo et al., 2003). Our observations during this study also showed that jaguars killed dogs at relatively high frequencies, which may be explained by their opportunistic behaviour when dogs are abundant and readily available.
Similar behaviour was observed amongst wolves in Minnesota, USA, and Finland (Fritts \& Paul, 1989; Lescureux \& Linnell, 2010). The overabundance of abandoned dogs and cats in most communities of Calakmul and Lacandon Forest may have implications for wild carnivores preying on them because of the risk of transmission of zoonotic diseases and parasites (Guerrero, 2011).

Reducing conflict between wild predators and livestock breeders is required in Calakmul and Lacandon Forest. Carnivores and other predators are facing habitat fragmentation and uncontrolled hunting by livestock breeders attempting to mitigate losses of livestock (Garcia-Alaniz et al., 2010). Better husbandry practices such as keeping sheep, goats, calves, pigs and poultry in safer enclosures at night could help reduce predators (and retaliation by breeders). Other possibilities include: relocating risky enclosures to safer places when possible, training healthy local guard dogs, launching programmes to reduce the overabundance, and improve the health, of dogs and cats in rural communities, and regulating local subsistence hunting of wild prey to improve food availability for wild predators.

The results of this research will be useful for reducing conflict with wild predators, taking into account the needs of people and predators in south-east Mexico. However, achieving this will require more information on the abundance of wild and domesticated prey, feeding habits of predators, and efficacy of livestock management strategies. Some of these matters are now being assessed by local research teams using multidisciplinary and participatory approaches. In addition, a field manual containing recommendations to mitigate livestock predation by wild carnivores was prepared following our study and has been distributed to breeders in the Lacandon Forest and Calakmul, so far with encouraging results.

\section{Acknowledgements}

We thank the financial and logistic support provided by ECOSUR, CONACYT, and project: Innovación socioambiental para el desarrollo en zonas de alta pobreza y biodiversidad de la Frontera Sur de México (CONACYTFORDECYT, reg. 116306). Many residents of Playon de La Gloria, Loma Bonita, Nuevo Becal and 20 de Noviembre kindly helped us in various ways. Manuel Weber provided insightful comments. Heberto González Pérez, Rubén Jiménez Alvarez, Nicolás Arias, Enrique Tamay, Fredy Falconi Briones, Luis Villaverde Limón, Arnoldo Villaseñor Pérez and Avril Figueroa assisted us during the fieldwork.

\section{References}

Amador, S.A. (2011) Evaluación de la depredación de animales domésticos por carnívoros silvestres en comunidades aledañas a dos áreas naturales protegidas del sureste de México. MSc thesis, 
El Colegio de la Frontera Sur, San Cristóbal de Las Casas, Chiapas, Mexico.

ARANDA, M. (2000) Huellas y otros rastros de los mamíferos grandes $y$ medianos de México. INECOL-CONABIO, Mexico City, Mexico.

Arguelles, L., Palafox, C., Villaseñor, A. \& García, F. (2009) Ordenamiento territorial comunitario ejido Veinte de Noviembre, Calakmul, Campeche. TROPICARURAL SPR, Campeche, Mexico.

Avery, M.L. \& Cummings, J.L. (2004) Livestock depredation by black vultures and golden eagle. Sheep and Goat Research Journal, $19,58-63$.

Azevedo, F.C. \& Murray, D. (2006) Evaluation of potential factors predisposing livestock to predation by jaguars. The Journal of Wildlife Management, 70, 2379-2386.

Baker, P., Boitani, L., Harris, S., Saunders, G. \& White, P. (2008) Terrestrial carnivores and human food production: impact and management. Mammal Review, 38, 123-166.

Bueno, A. (2004) Impacto del puma (Puma concolor) en ranchos ganaderos del Area Natural Protegida 'Cañón de Santa Elena', Chihuahua. MSc thesis, Instituto de Ecología, A.C. Xalapa, Veracruz, Mexico.

BUtLER, J.R. (2000) The economic costs of wildlife predation on livestock in Gokwe communal land, Zimbabwe. African Journal of Ecology, 38, 23-30.

Ceballos, G. \& Oliva, G. (eds) (2005) Los mamíferos silvestres de México. CONABIO-Fondo de la Cultura Económica, Mexico City, Mexico.

Ceballos, G. \& Simonetti, J. (2002) Diversidad y conservación de los mamíferos neotropicales. CONABIO-Instituto de Ecología UNAM, Mexico City, Mexico.

Crawshaw, P.G. \& Quigley, H.B. (2002) Hábitos alimentarios del jaguar y el puma en el Pantanal, Brasil, con implicaciones para su manejo y conservación. In El Jaguar En El Nuevo Milenio (eds R. Medellin, C. Chetkiewicz, A. Rabinowitz, K.H. Redford, J.G. Robinson, E. Sanderson \& A. Taber), pp. 223-236. UNAM, Mexico City, Mexico.

De Haan, C., Schillhorn, T., Brandenburg, B., Gauthier, J., Le Gall, F., Mearns, R. \& Simeon, M. (2001) Livestock Development, Implications for Rural Poverty, The Environment, and Global Food Security. The World Bank, Washington, DC, USA.

FrITtS, S. \& PAUL, W. (1989) Interactions of wolves and dogs in Minnesota. Wildlife Society Bulletin, 17, 121-123.

Garcia-Alaniz, N., Naranjo, E.J. \& Mallory, F.F. (2010) Human-felid interactions in three mestizo communities of the Selva Lacandona, Chiapas, Mexico: benefits, conflicts and traditional uses of species. Human Ecology, $38,451-457$.

Guerrero, S. (2011) Riesgo zoonótico y antropozoonótico en carnívoros silvestres pequeños y medianos en Calakmul, Campeche. MSc thesis, El Colegio de la Frontera Sur, San Cristóbal de Las Casas, Chiapas, Mexico.

Gula, R. (2008) Wolf depredation on domestic animals in the Polish Carpathian Mountains. Journal of Wildlife Management, 72, 283-289.

Hernández, A. (2009) Conflictos entre animales y humanos: la percepción de la depredación en Yucatán, México. MSc thesis, Centro de Investigación y Estudios Avanzados del Instituto Politécnico Nacional Unidad Mérida, Yucatán, Mexico.

Hoogesteijn, R. (2001) Manual sobre problemas de depredación causados por jaguares y pumas en hatos ganaderos. Grupo Asesor de Jaguar. Wildlife Conservation Society, Campo Grande, Brazil.

Hoogesteijn, R. \& Hoogesteijn, A. (2008) Conflicts between cattle ranching and large predators in Venezuela: could use of water buffalo facilitate felid conservation? Oryx, $42,132-138$.
INe (Instituto Nacional de Ecología) (2000a) Programa de Manejo Reserva de la Biosfera Montes Azules. Secretaría de Medio Ambiente, Recursos Naturales y Pesca, Mexico City, Mexico.

INe (Instituto Nacional de Ecología) (200ob) Programa de manejo, Reserva de la Biósfera Calakmul, México. Secretaría de Medio Ambiente, Recursos Naturales y Pesca, Mexico City, Mexico.

InSKip, C. \& ZimmermanN, A. (2009) Human-felid conflict: a review of patterns and priorities worldwide. Oryx, 43, 18-34.

LeOpold, S. (1959) Wildlife of Mexico, the Game Birds and Mammals. University of California Press, Berkeley, USA.

Lescureux, N. \& Linnell, D.C. (2010) Knowledge and perceptions of Macedonian hunters and herders: the influence of speciesspecific ecology of bears, wolves, and lynx. Human Ecology, 38, 389-399.

Linnell, J., Odden, J., Smith, M., Aenes, R. \& Swenson, J. (1999) Large carnivores that kill livestock: do "problem individuals" really exist? Wildife Society Bulletin, 27, 698-705.

Lowney, M. (1999) Damage by black and turkey vultures in Virginia, 1990-1996. Wildlife Society Bulletin, 27, 715-719.

Martínez, G. (2003) Utilización de fauna silvestre en la sierra de Álvarez, San Luis Potosí. MSc thesis, Instituto de Ecología, A.C. Xalapa, Veracruz, Mexico.

Mazzolli, M., Bartlet-Ryan, C. \& Graipel, M. (1997) Effects and patterns of mountain lion predation of livestock on small and medium sized properties in Santa Catarina, Brazil. In Proceedings of the 5th Mountain Lion Workshop (ed. W. D. Padley), pp. 54-61. The Wildlife Society, San Diego, California.

Mertens, A. \& Promberger, C. (2001) Economic aspects of large carnivores-livestock conflicts in Romania. Ursus, 12, 173-18o.

Michalski, F., Boulhosa, R., Faria, A. \& Peres, C. (2006) Human-wildlife conflicts in a fragmented Amazonian forest landscape: determinants of large felid depredation on livestock. Animal Conservation, 9, 179-188.

Nallar, R., Morales, A. \& Gomez, H. (2008) Manual para el reconocimiento de eventos de depredación del ganado por carnívoros altoandinos. Wildlife Conservation Society, La Paz, Bolivia.

Namgail, T., Fox, J. \& Bhatnagar, Y. (2007) Carnivore-caused livestock mortality in Trans-Himalaya. Environmental Management, 39, 490-496.

Naranjo, E.J. (2002) Population ecology and conservation of ungulates in the Lacandon Forest, Mexico. PhD thesis, University of Florida, Gainesville, USA.

Naranjo, E.J., Guerra, M.M., Bodmer, R.E. \& Bolaños, J.E. (2004) Subsistence hunting by three ethnic groups of the Lacandon Forest, Mexico. Journal of Ethnobiology, 24, 233-253.

Ogada, M., Woodroffe, R., OGuge, N. \& Frank, L. (2003) Limiting depredation by African carnivores: the role of livestock husbandry. Conservation Biology, 17, 1521-1530.

Polisar, J., Maxit, I., Scognamillo, D., Farrell, L., Sunquist, M. \& EisenberG, J. (2003) Jaguars, pumas, their prey base, and cattle ranching: ecological interpretations of a management problem. Biological Conservation, 109, 297-310.

ReID, F.A. (1997) A Field Guide to the Mammals of Central America and Southeast Mexico. Oxford University Press, New York, USA.

Romañach, S.S., Lindsey, P.A. \& Woodroffe, R. (2007) Determinants of attitudes towards predators in central Kenya and suggestions for increasing tolerance in livestock dominated landscapes. Oryx, 41, 185-195.

Romero, K., Naranjo, E., Morales, H. \& Nigh, R.B. (2006) Daños ocasionados por vertebrados silvestres al cultivo de maíz en la selva Lacandona, Chiapas, México. Interciencia, 31, $276-283$. 
Rosas, O., Bender, L. \& Valdez, R. (2008) Jaguar and puma predation on cattle calves in Northeastern Sonora, Mexico. Rangeland Ecology \& Management, 61, 554-560.

SACKS, B. \& Neale, J. (2007) Coyote abundance, sheep predation, and wild prey correlates illuminate Mediterranean trophic dynamics. Journal of Wildlife Management, 71, 2404-2411.

Scognamillo, D., Maxit, I.E., Sunquist, M. \& Polisar, J. (2003) Coexistence of jaguar (Panthera onca) and puma (Puma concolor) in a mosaic landscape in the Venezuelan llanos. Journal of Zoology, 259, 269-279.

Stahl, P., Ruette, S. \& Gros, L. (2002) Predation on free-ranging poultry by mammalian and avian predators: field loss estimates in a French rural area. Mammal Review, 32, 227-234.

Weber, M. (2008) Un especialista, un generalista y un oportunista: uso de tipos de vegetación por tres especies de venados en Calakmul, Campeche. In Avances en el estudio de los mamíferos de México II (eds C. Lorenzo, E. Espinoza \& J. Ortega), pp. 579-592. CIBNOR, ECOSUR, IPN, UAEM, UAM, UNICACH and University of Veracruzana, Veracruz, Mexico.
Woodroffe, R., Lindsey, P., Romañach, S., Stein, A. \& RANAH, M.K. (2004) Livestock predation by endangered African wild dogs (Lycaon pictus) in northern Kenya. Biological Conservation, 124, 225-234.

ZAR, J. (1999) Biostatistical Analysis. Prentice-Hall, Englewood Cliffs, USA.

\section{Biographical sketches}

SaUl Amador-Alcala has studied use and management of wildlife in rural communities in arid and tropical areas of Mexico; his current interests are focused on resolving conflicts between wildlife and humans. EDUARDO J. NARANJO is interested in the study of wildlife ecology, conservation, and management in tropical areas of Mexico and Central America. Guillermo Jiménez-Ferrer is a researcher interested in sustainable livestock grazing, agroforestry systems, local knowledge, and environmental services in rural areas of Mexico. 